Haya: The Saudi Journal of Life Sciences

Abbreviated Key Title: Haya Saudi J Life Sci

ISSN 2415-623X (Print) |ISSN 2415-6221 (Online)

Scholars Middle East Publishers, Dubai, United Arab Emirates

Journal homepage: https://saudijournals.com

Original Research Article

\title{
The Value of Life in Dayak Meratus Custom, Indonesian
}

\author{
Ahmad Herman ${ }^{1}$, Iim Wasliman ${ }^{2}$, Hanafiah ${ }^{3}$, Yosal Iriantara ${ }^{4}$, Budi Suryadi ${ }^{*}$ \\ ${ }^{1}$ Doctoral Student of Postgraduate Science Education School, Islamic Nusantara University, Indonesia \\ ${ }^{1},{ }^{2},{ }^{3}$ Postgraduate Science Education School, Islamic Nusantara University, Indonesia \\ ${ }^{5}$ Faculty of Social and Political Sciences, Lambung Mangkurat University, Indonesia
}

DOI: 1 10.36348/sjls.2021.v06i04.002 $\quad$ | Received: 17.03.2021 | Accepted: 24.04.2021 | Published: 29.04 .2021

*Corresponding author: Budi Suryadi

\section{Abstract}

Dayak indigenous communities have traditionally maintained and normalized the value of their ancestors, as a form of efforts to maintain these values, Dayak indigenous communities continue to perform rituals Balian in their interactive activities with nature. The research approach used is qualitative research with case study methods and research informants as a data source while data analysis techniques use stages of data collection, data reduction, data presentation and verification of conclusions conducted continuously until saturated. The results showed that the value of Dayak indigenous communities in the hall Kiyu hereditary upholds their pattern of life and relationship with nature. The value of life includes rice farming where rice is sacred and must be treated according to its dignity from planting to put back into the barn. According to belief, rice is a celestial plant and has decreased its dignity because it is in the dark world (real world, earth) must be restored to its sacred form of presenting various ceremonies for him who is sustainable.

Keywords: Value Of Life, Dayak Meratus Custom, Kiyu Hall.

Copyright (C) 2021 The Author(s): This is an open-access article distributed under the terms of the Creative Commons Attribution 4.0 International License (CC BY-NC 4.0) which permits unrestricted use, distribution, and reproduction in any medium for non-commercial use provided the original author and source are credited.

\section{INTRODUCTION}

Recognition of the value of life of Dayak Meratus people is also part of the cultural wealth of the Indonesian nation, which also received recognition from the state based on the 1945 Constitution, which states: "the state recognizes and respects the unity of the indigenous legal community and its traditional rights as long as it is alive and in accordance with the development of society and the principles of the Unitary State of the Republic of Indonesia, which is governed by the Law."

Values, traditions, customs, cultures that grow in a society is basically also an important asset or social capital in order to empower the community in order to realize the quality of life and welfare. In addition, the preservation of important traditions is done to entrench the excesses of modernization that destroy the bonds of traditional values such as kinship, cooperation, religious values, local customs, and cultural institutions that have actually been entrenched and rooted in the formation of social life.

In South Kalimantan, the term "Meratus people or Meratus tribe." Was used for approximately two years (1979-1981) while conducting research in the area. The term custom Dayak Meratus was originally initiated by Bingan Sabda, a local who studied at Gadjah Mada University, Yogyakarta - simply the term refers to their area of residence, the Meratus mountains [1].

Nevertheless, Meratus people more often identify themselves using the name of the village where they live. Meratus people prefer to identify themselves according to the name of the area of residence, the name of the river or based on neighborly or kinship relationships.

The identification is closely related to the sociocultural system to merits people based on familial relations. Bubuhan (group) is a collection of family consisting of the core family (father, mother and children). Bubuhan (group) is formed based on lineage or territorial similarity. Generally, Bubuhan (group) inhabits a hall or longhouse with a size of up to 30 meters and a width of 10-15 meters. Each family lives in a room in the hall or longhouse.

Dayak Meratus indigenous communities traditionally maintain and normalize the value of their ancestors, as a form of efforts to maintain that value, Dayak indigenous communities perceive continuously 
Ahmad Herman et al., Haya Saudi J Life Sci, Apr, 2021; 6(4): 63-73

perform rituals or beliefs that are implemented in their interactive activities with nature. The real form of activity is in land clearing ceremonies, plant events, harvests and post-harvest ceremonies.

For Dayak Meratus indigenous peoples, all elements of life, such as water, fire, soil, air, wood, iron, and stone are ruled by gods. Therefore, any effort related to using these elements must be done with respect and permission request in advance. Dayak Meratus indigenous peoples do not have a materialist orientation and competitive nature. The natural resources they need are only taken adequately, according to their needs and abilities.

The forest is Mother Earth and the breath of life for the Dayak Meratus community. Therefore, what is done to the forest and nature is directly proportional to its maintenance efforts. Forests for Dayak indigenous peoples become the basis of ideology, social, in addition to supporting the sustainability of life and the economy. It is believed that God will send down reinforcements if the destruction is done. Therefore, there is a high level of harmonization between them and the forest, by protecting each other.

Utilization of forests and their contents is regulated by customary law. Those who violate are penalized. Fruit trees, honey trees (large trees where bees nest), resin trees, and sacred trees are forbidden to be felled. Violation of that provision will be in the law of fines handed over to the customary parties. In cutting down trees should also pay attention to the aspects of safety and not harm others. And if a fallen tree falls on a fruit tree, whether it belongs to oneself or someone else's, it must pay a fine according to the losses caused. If a felled tree hits someone else's house or cottage, it will also be fined. Similarly, in the process of burning the land, if it penetrates into the fields of others, then in the law fines in accordance with the losses.

The ability of Dayak indigenous communities to penetrate in the management of natural resources oriented to the future by paying attention to the survival of posterity in the future. The simple mindset through local wisdom embraced by Dayak Meratus indigenous peoples, turned out to have a tremendous effect. The simplicity of local wisdom is now proven to be able to save and maintain the continuity of human life today. Although, indeed, this form of local wisdom is formed on the basis of the complexity of their relatively smaller needs.

The value of closely related to humans, both in the field of ethics that govern human life in daily life, and the field of aesthetics related to the field of beauty. Even the value of an entry when people understand religion, culture, and diversity and local wisdom of a culture that has beauty and useful to the human being as a guide or handle life.
Value is something of value that is considered valuable, fair, good, true, and beautiful and becomes a guide or a self-restraint. The guidelines or self-restraint arise because of the meaning of value in the human being [2].

Forest as a 'home' for indigenous people Dayak Meratus is a unity that integrated the values and character of Dayak Meratus community. Forests not only serve in the survival of Dayak Meratus indigenous peoples, but are also a source of life sciences and values based on how they treat the surrounding nature.

Based on the initial study conducted, currently the traditional Dayak community Meratus in the form of ritual, tradition is still less in demand by the generation under it, especially in studying ritual science. The threat of global cultural expansion through the flow of information, technology is considered a threat to the sustainability of the character values that Dayak indigenous communities uphold.

The existence of traditional halls in Dayak indigenous peoples Meratus where the constellation of halls is where the families gather, socialize, consult, and establish a very strong relationship in one unit of residence. In this hall all the themes of their lives are studied, life activities are planned, social problems and other aspects are consulted and solved.

The results of cultural research were formed and developed as a manifestation of human response to the challenges that arise in the process of adaptation to the environment. These responses are based on a variety of basic needs grouped into biological, social and spiritual needs. In detail those basic needs include eating and drinking, heredity, physical comfort, security, pleasure and relaxation, moving and connecting with others, and improved development [3].

Ritual communication in the tradition of Bahuma custom Dayak Meratus in preserving the forest by upholding the value of farming tradition. Farming in Dayak traditional ethnic terms they call Bahuma. In the tradition of Bahuma contains the value of kaharingan rituals that Dayak traditions believe as a form of worship and respect for the spirits of their ancestors. All Dayak customs have a livelihood as farm farmers, thus Bahuma are very closely related to the forest. Bahuma are often seen as a form of forest destruction activity, especially by outsiders who do not understand the system and practice of the activity et.al., [4].

\section{METHOD}

The approach used in this study is a qualitative approach based on two reasons. First, the problem studied in this study is about the value of life of Dayak indigenous peoples at traditional ceremonies. Second, because it is based on the association of the problem studied with a number of primary data from the subject 
Ahmad Herman et al., Haya Saudi J Life Sci, Apr, 2021; 6(4): 63-73

of the study that cannot be separated from the daily life of the community.

Researchers create complex images, examine words, detailed reports from the informant's view, and conduct studies on natural situations [5]. Qualitative methods are research procedures that produce descriptive data in the form of written and spoken words from people and observed behaviors [6].

This research was conducted at the Kiyu Traditional Hall of Hinas Kiri Village, Batang Alai Timur District, Hulu Sungai Tengah Regency. This study uses triangulation data collection techniques, namely in-depth interviews with research subjects, including Balian, indigenous stakeholders, village heads, NGO activists, village officials Hinas Kiri Batang Alai Timur Subdistrict, observation and document studies with research subjects, Balian, stakeholders, indigenous old men, village heads, observers and environmental activists.

The selection of research locus at Kiyu hall is based on purposive sampling, i.e. Locus is chosen based on the purpose that is adjusted for the purpose of research to explore the value of life of the Dayak Meratus indigenous community.

The data collection technique was conducted based on a complete observer, where researchers were not seen in the activities of the study subjects, but still made observations related to research objects using the five senses, especially the eyes and ears [7]. Close field observations, interviews are used to obtain primary data through unstructured interview techniques, and documentation studies in the form of document studies related to the value of life of Dayak Meratus indigenous communities.

Data analysis as a process of systematically finding and compiling data obtained from interviews, field records and documentation so that it is easy to understand and its findings can be informed to others. Data analysis using interactive analysis i.e. Data collection, data reduction, data presentation and conclusion drawing and verification [8].

The data process that has been submitted is done continuously by studying the data, grouping the data, finding what is important, according to the research problem and studying and deciding what to report. Through this analysis is attempted to reveal what data still needs to be searched, what questions to answer, what ways to update. The matrix of interactive data analysis, as follows:

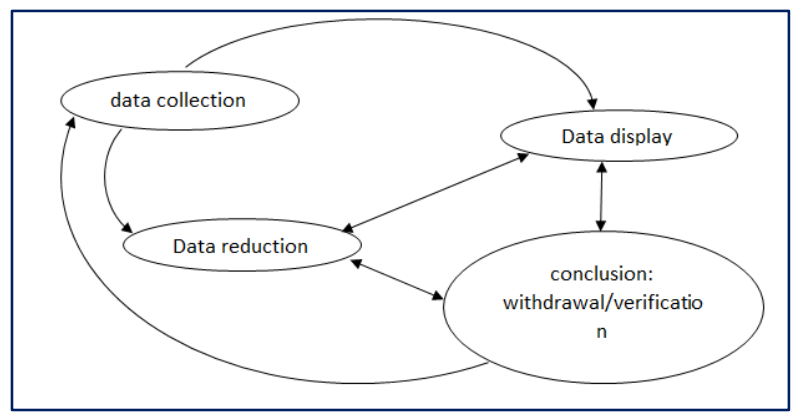

\section{RESULTS}

One of the indigenous communities in the South Kalimanatan Province, Dayak Meratus is a community that inhabits the mountainous region that divides South Kalimantan Province. It stretches for approximately 600 square kilometers of the Southeast and veers northwards, to the border of East Kalimantan. Meratus are part of nine districts in South Kalimantan, namely Kotabaru, Tanah Laut, Banjar, Tapin, Hulu Sungai Selatan, Hulu Sungai Tengah, Hulu Sungai Utara, Tabalong, and Balangan.

Meratus has a high biodiversity with some dominant vegetation, such as Meranti Putih, Meranti Merah, Agathis, Kanari, Nyatoh, Medang, Durian, Gerunggang, Kempas and Belatung. The forest area that is upstream is mostly a watershed, making this area very important for South Kalsimantan as a water catchment area.

In addition, it also describes a complete type of mountain forest ecosystem. Along the area of Meratus, there is a group of Dayak indigenous people known as Dayak Meratus. Since hundreds of years ago, it is this ethnicity that manages the Meratus area. Like the land, water, fields, crops, and living things around it, the forest is one part of the circle of life of Dayak Meratus indigenous peoples.

One of the Dayak indigenous communities located in the mountainous area of Meratus is Kiyu hilly. This community resides in the northern part of the Meratus mountainous area, along panghiki river and at the foot of Taniti (hill) Calang, which is administratively located in the area of Hinas Kiri Village, Batang Alai Timur District, Hulu Sungai Tengah Regency. Village Kiyu is a customs area covering an area of $\pm 7,632$ hectares and consists of two halls (traditional houses) namely Balai Kiyu and Haraan Hulu hall which oversee \pm 67 family. Most Kiyu people adhere to the ritual belief system (original religion).

Kiyu hall is administratively under the village government of Hinas Kiri. Hinas kiri itself has 2 halls, namely Datu Galung hall and Kiyu hall. The distance between the two halls is approximately 2 kilometers. In its history, the Hinas Kiri Village is a village that leads representatives of Pembakalun village, along with the 
Ahmad Herman et al., Haya Saudi J Life Sci, Apr, 2021; 6(4): 63-73

enactment of the Village Government System Law of 1974, there was an expansion of villages in the Dayak Meratus area. The Hinas Kiri Village stands alone in the Batu Kambar Village spoken from Hinas Kiri village. While Pembakulan village is divided into Atiran Village, Batu Perahu, Aing Bantai, Datar Batung.

Kiyu hall itself was still joined by the hall Datu Galung, but over with the increase of the population, and also caused by a considerable distance from Kiyu to the hall Datu Galung, then built Kiyu hall as a forum for the community in organizing traditional ceremonies. Until now Kiyu hall has undergone renovations with buildings that are all made of zincroofed wood with the title Pandirian Pakumpulan Kiyu hall custom, previously Kiyu hall made of walls of woven bamboo, bamboo floors, with Ijuk roofs, and inhabited by several families that inhabit the booths around the main hall.

The traditional institutions of Kiyu hall are separated from the hall Datu Galung, but their kinship is still one part. The separation of Kiyu hall was due to the increase in the population. Kiyu hall is located at RT 02 Hinas Kiri Village, while Kiyu hall is on RT 06.

Dayak Meratus institutions are in one traditional institutional organization of Batang Alai Timur Subdistrict, which oversees several hall units totaling 11 halls spread across 8 villages, namely: Hinas Kiri, Pembakulan, Muara Hungi, Atiran, Juhu, Datar Batung, Aing Bantai and Batu Perahu. In general, indigenous institutions covering the district of Batang Alai Timur have an organization that oversees the customary administrators at the hall level.

Hill people or Dayak indigenous peoples make a living by concocting forest products: resin and rattan. They farm in a mobile, rice field, and rubber gardening. Not only men who farm, but also women and children. Farming is a basic livelihood, while cultivating forest products and gardening, such as tapping rubber, as parttime work.

The existence of ceremonies at every stage of life, it is closely related to the belief system. The ceremonies are not independent and separate, but in a series. That's why, hill people are never quiet from activities in the form of a way, either before, during, or after doing a job.

The social life of Dayak indigenous communities has a life that upholds their relationship with nature. Every day they are always related to field activities, gardening, nature is the source of their lives. So that's what results from their efforts in field activities is always accompanied by ritual ceremonies.
The ritual ceremony that became the tradition of Dayak Meratus traditional community in the hall Kiyu Hinas Kiri village which was carried out for generations, as follows:

1. Baancak is a ceremony that is usually carried out after the completion of the opening of the land will be used as a field, so that the hope of the local people get fortune or good luck in one year. And given safety in doing the next stage of the field is planting rice. Baancak ceremony is done when the land clearing activity is finished, and will enter the rice planting activities;

2. Pasit rice is a ceremony that is usually performed after the rice is harvested from the land, the purpose of the rice Pasit ceremony is to give gratitude to the creator. The ceremony is intended as an expression of gratitude community Dayak Meratus because it has given good results. This ceremony also gives sacredness to the harvest, namely rice that is considered as a sacred plant;

3. Basambu Umang is a ceremony that is usually held over seven months of rice, this ceremony aims to prevent the rice from being damaged until it can be harvested. Dayak Meratus indigenous community, especially in the hall Kiyu Hinas Kiri village is very sanctifying rice as a commodity planted by them. Not only rice as a staple food, but more than that rice is considered as a consecrated plant, and the purification of rice is done through Aruh;

4. Batumbang Paring is a ceremony commonly held in the forest that is attended by residents who have opened land. The function of the implementation of Batumban Paring ceremony aims to ask for safety in the felling of trees so as not to harm the trunk of citizens who conduct land clearing activities, as the initial stage of field activities;

5. Balanggatan / Bawanang is a ceremony that is usually held once every five years, where this ceremony can only be carried out if the community has opened land for 5 years in a row without interruption new Balanggatan ceremony is carried out. The event was held six days and six nights. Aruh Bawanang is an expression of gratitude for the abundant harvest. In Aruh, Balian is tasked with connecting the underworld with the upper world. Including, dealings with the spirits of the deceased men. Aruh Bawanang is also known as Aruh Ganal. That is, a great traditional ceremony. So-called because it is carried out massively by all villagers. Also, attended by invitations coming from other villages.

While Aruh Kecil, done only in the family environment only. Aruh Bawanang is also only held if the harvest is in accordance with the expectations of the citizens. In addition to gratitude, Bawanang, intended to ask the Almighty, so that in the coming year can again get abundant crops. Then, hope to be kept away from all dangers, diseases and destructive creatures. If the 
Ahmad Herman et al., Haya Saudi J Life Sci, Apr, 2021; 6(4): 63-73

harvest is not as expected, the residents only hold Aruh Kecil, or even not held at all.

Langgatan Papatangkalak or the mother of the offering container. The container is made of rectangular-shaped bamboo pieces. In the traditional ceremony, Langgatan Papatangkalak was hung in the middle of the hall. Decorated with strands of yellowing coconut leaves and other ornaments of cloth and foliage, create a rectangle. The hope is to protect all citizens from the dangers that come from all over.

The event was opened by the Balian, who sat around Langgatan Papatangkalak. Among them there is a Balian leader, namely the head of custom hall. He sat on a mat. The old man's mouth is in Bamamang. At the same time, the sounds of Gandang and Kalimpat were heard in the room. With the commencement of Bamamang, he told the Almighty that the ceremony was beginning.

In addition to asking permission to the Almighty for the ceremony to run smoothly, Balian also invited the spirits of ancestors or Datu to attend the event. After that, the Balian enjoyed wiping The Hiang Bracelet on a puff of frankincense smoke.

All of them, symbolizing things related to abundant crops, prayers and hopes. It was seen when the whole Balian surrounded Langgatan Papatangkalak while carrying natural results. Starting from good fruits, vegetables, and rice.

The dance known as Bakanjar Dance is just the beginning of the ritual of Aruh Bawanang Dayak tribe Meratus in Kiyu hall. They also put "milled" in the form of tobacco, lime, gambir rolled in betel leaves, as an intermediary to summon the spirits of the ancestors to be willing to accept the offerings of the citizens. Aruh Bawanang as a peak of Aruh procession conducted since Dayak indigenous community conducted land clearing until post-harvest activities.

\section{DISCUSSION}

The value of Dayak indigenous community Kiyu hall traditionally upholds their pattern of life and relationship with nature. Meratus Is a very fertile area with the flow of the Batang Alai River, which is the largest river in the District of Batang Alai Timur and is the main source of water for the Meratus community.

The life of Dayak indigenous peoples to make their daily life is Bahuma and farming. The type of plant they plant is rice. Rice has a very high value on the life of the people Meratus. Rice cannot be valued with money, rice for the community Meratus is a sacred plant that must be respected and sanctified through our ceremony.

A Dayak traditional community Kiyu hall believes that rice is sacred and should be treated according to its dignity since it was planted to put back in the barn. According to belief, rice is a celestial plant that was originally a foreign plant on the face of the earth.

Rice that has decreased its dignity because it is in the dark world (real world, earth) must be restored to its sacred form of presenting various ceremonies for him that is sustainable. Therefore the deeds in the form of ceremonies (Aruh) in the community are almost all around the worship of rice (God of Rice Keepers) and all activities related to the almighty.

The value of Dayak Meratus people is directly connected to the land (farming), because almost all Dayak cultures are sourced and glorify the land and rice. Therefore, their values are, generally, more polite, not expansive, and open. It becomes a kind of strength that the friendliness and modesty and modesty of people's lives are their strength to build togetherness and kinship, a unity that has no difference.

In addition, the value of Dayak Meratus indigenous community is Aruh or a ritual ceremony performed by Dayak Meratus indigenous communities in terms of carrying out each stage of field processing with Aruh. Aruh for the people of Kiyu hall is the value of life that is upheld. The value of life in Dayak indigenous communities is one of them is to preserve and preserve its nature in accordance with the beliefs of the local community. Cultural value or habit, namely by carrying out ceremonial activities / rituals that become a habit and culture of local residents.

In the development of Dayak Meratus community life, especially in Kiyu hall custom, there are various livelihoods made by members of the community, such as gardening, tapping rubber trees, and farming. This farm is what is seen as customary. Farming is the work and custom of the ancestors of the Dayak Meratus indigenous community.

Farming is not only the work of men, but also the work of women, even this work is also followed by children. Children since good at walking are included in all activities in the field such as opening land, decapitation (putting seeds into planting holes), squinting and waiting for the fields.

Since childhood Meratus children are given and experience the natural learning process of farming stages. Nature is a teacher for the child Meratus. They used to walk tens of kilometers, go up and down hills and mountains, hold heavy crops, follow all the events of respect for the stages of farming. All of these processes are a series of value transformations and efforts to strengthen the values that Dayak indigenous communities uphold Kiyu hall.

A series of Aruh or ceremonies begin when they are finished in determining the division of 
Ahmad Herman et al., Haya Saudi J Life Sci, Apr, 2021; 6(4): 63-73

plantation areas that will be carried out by members of the hall based on its division with customary deliberations. The value of sacred contained in local wisdom has a good impact on the environment. Management is carried out jointly to meet the needs together so as to create regularity.

Aruh is a value, owned and upheld by the Dayak Meratus indigenous community in Kiyu hall. A Dayak indigenous community of Kiyu hall upholds the value because the relationship with the creator can be seen in the Aruh event. Human relationships can be seen how customary fines threaten those who violate the custom: the example of fighting will be imposed a fine of so many conditions.

Dayak indigenous community Meratus Kiyu hall conduct customary law determination in customary deliberations, parties involved indigenous elders / stakeholders, in addition, there is also the head of the field, customary deliberations related to the direction of implementation of field activities in one season, for example 5 family direction to where in carrying out land clearing.

Everything is completely scheduled and not careless. 1-2 days later planned to cut down the wood, they're consulted again to prepare cakes / offerings in the hall Kiyu, this activity aims to reject the reinforcements at the time of land clearing held.

The Aruh activity, family that carried out the land clearing hopes that all residents of Kiyu hall are given safety during the work process, no workers are affected and injured. After the land clearing activities are completed, usually left $1 \log /$ tree to be given worship. One log or a tree that is left behind is intended as an end to land clearing activities.

This means that there will be no more logging process afterwards, or as a proof that the work has been completed, and there will be plant activities or planting process. Land that is ready to be planted with rice and other commodities such as corn, beans, cucumbers. The family will carry out ceremony Baancak as a form of application so that in the procession of planting the results they get in accordance with their expectations.

The real result of the ceremony is done, mentioning members of the Dayak Meratus indigenous community who do the work of safe and healthy, then the seeds produced are good, then they pray that the good seeds in the future are again granted, so that we can re-implement the Aruh event.

Aruh is the promise of Dayak indigenous community in the hall Kiyu, be it individual promises and collective promises. If the seeds are good, can hold or event, working people are safe and healthy, it is all enough for the Dayak indigenous community Meratus and has become a value of happiness for the citizens of Kiyu hall.

In addition to Aruh, land for this community is also considered very important, the land ownership system is based on agreement and trust and belief in customary rules. It is extraordinary when it is strictly adhered to even though it is not stated in a form of written rules.

The boundary of a Tambit (land ownership) is characterized by the planting of perennials such as rubber, cinnamon, bamboo groves, straight wood, betel nut trees, and rivers. The determination of this boundary is based on agreements between landowners that are directly adjacent so it is very rare to cause problems. Dayak indigenous peoples know the land ownership system based on inheritance, marriage, buying and selling, and rent.

Based on inheritance, the land is given by the parents to the child based on the ability of management of the child, regardless of gender. Based on marriage, land ownership can be granted if one of the residents marries an outsider, but decides to remain there. In this case, it is granted a land management permit around the hall where it lives.

Land ownership based on buying and selling only applies to people in one area of custom hall. The rental system must obtain approval from the head of custom, provided only for planting short-term crops or crops. Land ownership can be lost if the owner dies or is abandoned for a long time, while the time left behind is not planted with perennials. The land for Dayak Meratus indigenous community is the origin of man. Therefore, the land as a treasure gets a very high respect and cannot be treated carelessly.

Dayak indigenous community Meratus in preserving the value of involving children throughout the family of small children to the elderly in all activities are, with the intention of providing an early understanding for children that this is the customs of Dayak Meratus people. Then in the way of the Father, give information orally / speech to his children how a person should carry out the commands of the belief system they follow, carrying out the tradition that is carried out through generations.

By involving the younger generation in every ceremonial activity, Kiyu hall indigenous community strives to maintain the values held high in the hall Kiyu, and carried out continuously by the lower generation.

The life of Kiyu hall people is patterned on field activities. All family units, family heads, wives, and children are involved in the activity. In the morning, parents and children with woven backpack and machetes around their waists and dogs go to their 
Ahmad Herman et al., Haya Saudi J Life Sci, Apr, 2021; 6(4): 63-73

fields, some taps rubber to get rubbery, some go to the fields to see the crops they grow, all of them take place with simplicity and simplicity.

The characteristic of Dayak Meratus indigenous community as a beginner community is to hold it strictly to the custom. This custom is the rule of their lives. According old man and former village head of Hinas Kiri the custom should not be violated. If this happens then the offender will experience a civility, namely the curse of the ancestors who look in the form of consecutive calamities and prolonged diseases that befall the concerned.

It is also believed that the calamity or calamity not only befalls the concerned but also befalls all people and their Bubuhan (group). For Dayak Meratus custom, indigenous community is the root of life. If a person does not obey him anymore, then he will be excluded from his Bubuhan (group) and from all Bubuhan (group). The person concerned must live and live among the Trade People. Based on research conducted by the Research Institute of Indigenous Peoples of South Borneo, the daily life of Dayak indigenous peoples is full of policies and high wisdom. Everything is done with respect to nature and the spirits of the ancestors as guardians.

The value of Dayak indigenous community is especially in the hall Kiyu in Aruh activities or traditional ceremonies, adherence to customary law, character on natural management in field activities, on kinship patterns with the existence of the hall as a symbol of unifying Dayak Meratus indigenous community, the existence of Balian as a symbol of trust and character booster figures Dayak Meratus community.

Dayak Meratus community in the hall Kiyu starts from a collection of values, the value system is manifested in the system of ceremony, which contains a system of beliefs and beliefs, values in the procession of opening field activities, values in the management of land and land, kinship system which is all a cycle of life carried out by the Dayak indigenous community that is linear with the thoughts, attitudes and behaviors displayed by the Dayak Meratus indigenous community.

Dayak Meratus indigenous people basically have three unique values, namely the value of belief or belief, social, and culture. These three values are a whole and inseparable unity in the cultural traditions and wisdom of Dayak Meratus indigenous peoples. In the religious system / beliefs Dayak Meratus indigenous people have introduced the value of tolerance, respect for others despite different beliefs, and put forward the common good.
Basically, a ceremony is not only a series of behaviors of a person or group of people communicating with something he considers and that is seen as grasping the fate of life, but also communicating and improving everything that he believes is true to all his followers. In the latter case, it is said to carry out an educational function, which is an action in the process of socialization and acculturation of everyone. In addition, the ceremony itself is a place for people who learn to be Balian or improve their scientific rank, master the Mantra, improve the skills of making equipment and offerings [9].

The ceremony throughout the farming activities is generally communal or at least involves several families. At the summit ceremony, all family and all citizens are required to participate with all certain tasks outlined by the head of customs.

For agricultural issues such as the search for new land, the head of customs is assisted by the head of the field. $\mathrm{He}$ is the one who knows more about the traditional boundaries of Bubuhan (group), which areas can be opened and cultivated and which areas are forbidden to be used as fields and so on. If there is a dispute between the two Bubuhan (group) then the two heads of the field are asked to consider it.

Dayak Meratus indigenous people highly uphold values and traditions, an obligation for Dayak indigenous peoples know the boundaries of any territory that is allowed to be worked on, to live in and which areas should be protected.

Although it is not stipulated in a written law, but the boundaries of the territories must be obeyed because it relates to the punishment of God. In believing, if the customary provisions that apply in ignored, then the concerned will endurance which leads to misfortune.

Dayak indigenous people understand very well that the land has limited fertility rates. Therefore, its utilization is done wisely using a reverse grinding pattern or in the community now called a moving field.

After Pahumaan (fields) opened by cutting and burning, then planted rice and crops one to three plantings. It is done to overcome soil fertility rates and avoid erosion. In addition, soil fertility will be reduced so that it must be restored first by abandonment. After 10 to 15 years, when the trees grow again, the location is visited and reopened.

The forest is the motherland and the breath of life for Dayak Meratus indigenous peoples. Therefore, what is done to the forest and nature, is directly proportional to its maintenance efforts. Forests for Dayak indigenous peoples become the basis of ideology and social, in addition to supporting the sustainability of 
Ahmad Herman et al., Haya Saudi J Life Sci, Apr, 2021; 6(4): 63-73

life and the economy. It is believed that God will send down reinforcements if destruction is done. Therefore, there is a high level of harmonization between them and the forest, by protecting each other.

Utilization of forests and their contents is regulated by customary law. For those who violate, imposed sanctions. Fruit trees, honey trees (large trees where bees nest), resin trees and sacred trees, are forbidden to be cut down. Violations of that provision will be subject to fines handed over to the customary parties.

In cutting down trees should also pay attention to the aspects of safety and not harm others. If the tree that will be felled falls on the fruit tree either owned by himself or someone else, must pay a fine according to the losses caused.

If a felled tree hits someone else's house or cottage, a fine will also be imposed. Similarly, in the process of burning the land, if it penetrates into the fields of others, then in the law fines according to the losses caused.

In Dayak Meratus indigenous peoples, there are five basic principles in the management of natural resources. Namely sustainable, togetherness, biodiversity, sub-systems and compliance with customary law. Through the implementation of these five principles, Dayak Meratus indigenous people play an active role in maintaining the sustainability of nature.

In addition, Dayak indigenous peoples believe in their local wisdom as a form of communication to fellow human beings, nature, and God. Local values and wisdom that are then taught from generation to generation in the midst of various changes in the order that occur, the value of "perennial" that continues to be taught and become the shaper of the character of the power person in looking at himself, looking at the relationship with others, his relationship with outside the power person, his relationship with nature and his relationship with the Creator

Through the implementation of these five principles, Dayak Meratus indigenous people play an active role in maintaining the sustainability of nature. Dayak indigenous peoples believe in their local wisdom as a form of communication to fellow human beings, nature and God.

What is in the value of Dayak indigenous communities is established in this study, in accordance with the opinion of Lickona [10], the value is a compatible mixture of all the goodness identified by religious traditions, literary stories, the wise, and the collection of common-minded people that exist in history.
Goodness in organizing nature, and treating the land as a source of livelihood, as well as water governance proves that the character of Dayak Meratus indigenous peoples are guardians of natural sustainability, through religious traditions, which as hill peoples' religion.

The simple mindset through local wisdom embraced by the Dayak Meratus indigenous community, turned out to have a tremendous effect. The simplicity of local wisdom is now proven to be able to save and maintain the continuity of human life now in relation to nature.

Although it is, the form of local wisdom is formed on the basis of the flexibility of their relatively smaller needs. The value of sacred contained in their local wisdom, proven to have a good impact on the environment. Management is carried out jointly to meet shared needs, thus creating social order.

The position of forest areas that are upstream of most of the watershed makes this area very important for South Kalimantan Province as a water catchment area. On the other hand, the condition of land marbles is quite steep and the type of soil that is sensitive to erosion makes it has a high vulnerability value.

Various considerations above and also the function of environmental comfort for people downstream, the closure of forests are the only option, so the forest area of the Meratus Mountains should be maintained as a protected forest and kept away from destruction. Based on the type of land closure of the area

Meratus Mountains geographically, can be divided into three, namely: Highland Forest $(+11,345$ ha), Mountain Forest (+ 26,345 ha) and Unproductive Dry Land (+ 8,310 ha). While based on Okuler observations in Al Fatah \& Minar (2004)., most of the land use around the protected forest of Meratus Mountains is agricultural area, secondary forest to shrubs and plantations of the people.

Then among the Dayak community in general, there are now two understandings related to "village" as a place to live and livelihood. The first is called "green village" and the second is Banua. "Green village" is a distance that is generally in the form of mountain peaks and surrounding areas that are still densely forested. In the distance the place appears green. It is believed that in the "green village" there are a number of subtle creatures, the spirit of Datu Nini who has not yet arrived at Maratusi hall, and the spirit that maintains the area. Banua is a village where people live, where they live and make direct use of all the resources in the place. 
Ahmad Herman et al., Haya Saudi J Life Sci, Apr, 2021; 6(4): 63-73

Thus the village in the second sense of Dayak Meratus people is their traditional area in which there is a hall or several huts around it, fields that are scattered around it along with temporary or relatively long-lived huts and Bubuhan (group) forest areas (rattan forests or resin forests) that can be benefited. Thus, every bubuhan (group) owns and occupies his own village.

At the front of the hall there is always an open space called a courtyard. This open space is not only used for drying rice, but for traditional or religious ceremonies. Because in certain places in the open space it is usually placed Sangga (magical sacred objects to protect the village and people from disturbances and dangers) then the open space is also named Manyangga court.

The layout in the hall is as follows. There are a number of spacious booths around $4 \mathrm{M} 2$. The room is a bed in each family, namely both parents, young children and unmarried girls. The central part of the hall is intended as a place for traditional and religious ceremonies.

In this place usually hanging Langgatan (both religious ceremony equipment). Between the family room and the ceremony room there is a place to sit around, a guest room and at the same time when the night becomes the morning bed of the unmarried virgins. Usually the kitchen and or place of residence are in front of their family booths.

Dayak Meratus people are traditional people who live in groups based on kinship ties in one traditional dwelling called traditional halls. Physically, the traditional hall has several cubicle spaces surrounding the communal and ceremonial halls, using natural materials, and is built under a simple construction [12].

Meanwhile, in view of the aspect of belief, according to [13], the belief or religion of Dayak Meratus indigenous community is field religion. Some aspects of field religious in contain the belief that rice is a sacred plant, the obligation to maintain and glorify rice, and carry out various ceremonies to purify rice. Therefore, the traditional halls as dwellings are built to move around following the location of the fields.

Customs hall serves as a place or place to gather for Dayak Meratus indigenous community in conducting deliberations, more importantly the role and function of the hall as a place for organizing customary Aruh and wedding ceremonies. Formerly a traditional hall in addition to being a place of ceremony hall is also a residence for families who inhabit the room that becomes a unit with the hall.

The hall in addition to being a place of residence for the residents of the hall, is also a symbol of kinship owned by the Dayak Meratus community. Their closeness in one place of residence, making Dayak indigenous community emotionally united, the process of deliberation always occurs because of the proximity factor. The dominance of the hall as the leader of the hall became a highly respected figure and respected by the family.

The function of the hall can also be used as a unifying symbol to negate social status among Dayak Meratus people. In the function of the hall as a residence all family is in the same social status, as citizens of the hall with the same rights and obligations. They are bound by a very high sense of brotherhood, the value of pleasing help, the value of character strict on customs and upholding ancestral heritage.

This value is still firmly ingrained among the Dayak indigenous community until now. Although the current condition of Dayak Meratus community life adjusts to the pattern of housing itself, but the value contained in the function and role of the hall is still firmly embedded as a unifying symbol of their existence.

The emergence of a new customary hall is a change marked by the breakup of a customary hall caused by an increasing number of families, either because of marriage (wives following husbands and the birth of children) or the joining of families from other customary hall groups. Due to the large number of families and not accommodated in the halls, based on the agreement, a new hall was built. Fractional customary halls usually use the same name as the parent halls. And from the findings of the research the emergence of Kiyu hall, which separates with the hall Datu Galung et.al., [14].

Another cause of the rupture of the customary hall, although rare, is the existence of internal conflicts within the group. If it happens and no solution is found, some families will move to another group or build their own customary halls. This is possible because there is no limit to the minimum number of families allowed to build a new customary hall. As long as in a traditional hall there are Balian then they are able to build their own group or traditional hall.

Another cause is the wanting of a group of people from a group that once existed in order to rebuild their customary halls. This is based on the desire to restore the pride or glory of the group. The change marked by the loss of a customary hall is due to several reasons.

The first reason is the absence of group members who are able to become Balian. As a result, in the group or hall-custom, no one can lead the implementation of the traditional ceremony (Aruh). This means a lot to the Dayak Meratus tribe. In this 
Ahmad Herman et al., Haya Saudi J Life Sci, Apr, 2021; 6(4): 63-73

case, usually the residents of the group will move to another group that still has family ties, so that their halls eventually become lost. Another reason is the transfer of beliefs.

This phenomenon was once happen in the group of traditional halls in the Dayak area Meratus Loksado which most of its citizens converted to Islam and Christianity. Meanwhile, a small number of other residents joined the other traditional halls, as a result of which the Loksado customary hall was lost.

The shift in the function of the customary hall cannot be separated from the changes outlined above. There are several interrelated conditions and influence the shift in the function of the customary hall, namely (1) while the citizens of a group no longer live in the hall-custom, (2) have built and lived in privately owned houses, (3) still hold religious beliefs fields and carry out Aruh, and (4) choose economic capabilities.

Furthermore, when the traditional halls were rebuilt, the Dayak people built them without cubicle space. However, there are also community groups that still maintain this cubicle space as a marker of ownership and identity of group members [15].

Customs hall is a symbol of unifying Dayak Meratus indigenous community, statically the hall is a forum in organizing various customary activities and traditions. In carrying out the function of the hall is carried out by the function of the head of customs along with its ranks. The structure of the traditional hall in the Dayak Meratus indigenous community is a collegial rank and consists of indigenous figures, indigenous religious figures custom. So the decision-making authority on Dayak indigenous community Meratus takes place in the process of consensus deliberation.

The function of the head of the custom in the community, is not much different from the function of customary law, because the functions of the Head of custom in the community are as follows, namely:

1. Provide guidance to members of the community, how to behave in public life, and is the basis of such behavior is a habit that is hereditary;

2. Maintain the integrity of the alliance in the community, so that the alliance is maintained and can be felt by various actions of community members that are not in accordance with the customs and customary laws;

3. Give a handle members of the community to hold customary law as social control. Social control is more supervisory about the behavior of the community so that the life of the alliance can be maintained as best as possible;

4. Pay attention to every decision that has been determined by the head of custom, so that the decision has authority and can provide legal certainty that binds all members of the community;
5. Is a place where members of the community rely to resolve, protect and guarantee peace, then the head of the custom is the only place where members of the community lean to solve the problem;

6. As a place where members of the community ask everything related to the knowledge of customs and customary law. This is very important because not all members of the community know, understand and understand about the intricacies of customs and customary law. With such a function, the head of the custom can be said as a medium of information on customs and customary law in the community;

7. As a place for members of the community to solve all problems, both related to life and affairs related to death. The function is very important because members of the community are not all able to solve the problem on their own unless they ask for the involvement of the Head of custom to participate in solving it;

8. As the father of the community who heads the alliance [16].

In addition, the important job of the head of custom is a job in the field or a job as a Village Peace Judge. If there are disputes or actions that are contrary to customary law, then the head of custom acts to restore customary peace, restoring balance in the village atmosphere.

To resolve and restore the balance disorder, it is certainly necessary the role and function of the customary head in order to create peace and tranquility in the community. The function of the customary head is in charge of maintaining a harmonious life in the alliance, keeping it running properly.

The activities of the head of daily customs cover the entire field of community life. There is not a single field of social life in the alliance that is closed for indigenous heads to intervene when necessary to maintain peace, peace, balance of birth and mind.

Dayak Meratus tribe in South Kalimantan has a unique culture and positive values contained in their culture, such as honesty, respect and respect for rice spirits, preserving forests for generations, promoting benefit of others, and religious tolerance. Also the most unique in their culture is Bahuma (farming) which is a belief value system combined with farming traditions. The highlight of the Bahuma tradition is the Aruh Ganal ceremony.

Family values based on blood ties are the most basic, the existence of indigenous leaders and religious figures are highly respected, obedience is their key in dealing with various life problems in addition to the spirit of togetherness and please help. 


\section{CONCLUSION}

The value of Dayak indigenous community in the hall Kiyu traditionally upholds their pattern of life and relationship with nature. The value of life includes rice farming where rice is sacred and must be treated according to its dignity from planting to put back into the barn. According to belief, rice is a celestial plant and has decreased its dignity because it is in the dark world (real world, earth) must be restored to its sacred form of presenting various ceremonies for him who is sustainable.

\section{REFERENCES}

1. Tsing, A. L. (1993). In the realm of the diamond queen: Marginality in an out-of-the-way place. Princeton University Press.

2. Djahiri (2010). Esensi pendidikan Nilai Moral Dan Pkn Di Era Globalisasi. Bandung:LPPP-IPS IKIP

3. Radam, J. R., \& Patel, K. B. (2001). Effect of saline water through drip irrigation system on yield and quality of tomato. Journal of Maharashtra Agricultural Universities (India).

4. Fahrianoor, F., Dida, S., Rizal, E., \& Agustin, H. (2018). Komunikasi Ritual pada Tradisi Bahuma Etnis Dayak Meratus dalam Melestarikan Hutan. Prosiding Konferensi Nasional Komunikasi, 2(01), 121-129.

5. Moleong, L. J. (2013). Metodologi Penelitian Kualitatif (ketigapulu). Bandung: PT Remaja Rosdakarya.

6. Bogdan, R., Taylor, S. J., \& Taylor, S. S. (1975). Introduction to qualitative research methods: A phenomenological approach to the social sciences. Wiley-Interscience.

7. Creswell, J. W. (2009). Mapping the field of mixed methods research.

8. Miles, M. B., \& Huberman, A. M. (1994). Qualitative data analysis: An expanded sourcebook. sage.

9. Radam, J. R., \& Patel, K. B. (2001). Effect of saline water through drip irrigation system on yield and quality of tomato. Journal of Maharashtra Agricultural Universities (India).

10. Lickona, T. (1991). Educating for character: Mendidik untuk membentuk karakter. Jakarta: Bumi Aksara.

11. Yasir Al Fatah \& Betty Tio Minar/LPMA. (2004). Menggali Kearifan di Kaki Pegunungan Meratus. intip hutan. Banjarmasin: LPMA Borneo Selatan.

12. Muchamad, B. N. (2007). Anatomi rumah bubungan tinggi (Vol. 1). PT LKiS Pelangi Aksara.

13. Radam, J. R., \& Patel, K. B. (2001). Effect of saline water through drip irrigation system on yield and quality of tomato. Journal of Maharashtra Agricultural Universities (India).

14. Muchamad, B. N., Dharoko, T. A., Ronald, A., \& Ahimsa-Putra, H. S. (2020). Transformasi Permukiman Suku Dayak Bukit (dari Pondok menjadi Kampung). JOURNAL OF ARCHITECTURE AND PLANNING STUDIES.

15. Muchamad, B. N. (2007). Anatomi rumah bubungan tinggi (Vol. 1). PT LKiS Pelangi Aksara

16. Taneko, S. B. (1981). Dasar-dasar hukum adat dan ilmu hukum adat. Bandung: Alumni. 